\title{
Correction to: A study on causes of cattle liver condemnation at an abattoir in Omdurman area, Khartoum State, Sudan
}

Darien Kheder Ali Mohamed

\section{Correction to: BMC Vet Res 17, 58 (2021) \\ https://doi.org/10.1186/s12917-021-02766-4}

The original article [1] contained an error in presentation of author, Darien Kheder Ali Mohamed's name which has since been corrected.

Published online: 06 September 2021

\section{Reference}

1. Mohamed DKA. A study on causes of cattle liver condemnation at an

abattoir in Omdurman area, Khartoum State, Sudan. BMC Vet Res. 2021;17:

58 https://doi.org/10.1186/s12917-021-02766-4

The original article can be found online at https://doi.org/10.1186/s12917021-02766-4.

Correspondence: dareenkheder@gmail.com

Department of Veterinary Preventive Medicine Public Health, Faculty of

Veterinary Medicine, University of Khartoum, Khartoum North, Sudan

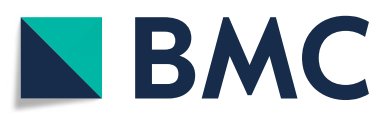

(c) The Author(s). 2021 Open Access This article is licensed under a Creative Commons Attribution 4.0 International License, which permits use, sharing, adaptation, distribution and reproduction in any medium or format, as long as you give appropriate credit to the original author(s) and the source, provide a link to the Creative Commons licence, and indicate if changes were made. The images or other third party material in this article are included in the article's Creative Commons licence, unless indicated otherwise in a credit line to the material. If material is not included in the article's Creative Commons licence and your intended use is not permitted by statutory regulation or exceeds the permitted use, you will need to obtain permission directly from the copyright holder. To view a copy of this licence, visit http://creativecommons.org/licenses/by/4.0/ The Creative Commons Public Domain Dedication waiver (http://creativecommons.org/publicdomain/zero/1.0/) applies to the data made available in this article, unless otherwise stated in a credit line to the data. 